„Tehetség, szorgalom, hivatás”

\author{
Tanulmánykötet
}

Kézirat lezárva: 2021. június 25. 
Kiadja:

a Magyar Rendészettudományi Társaság

Vám- és Pénzügyőri Tagozata

Szerkesztette:

Csaba Zágon és

Zsámbokiné Ficskovszky Ágnes

Felelős kiadó:

Szabó Andrea

ISBN: 978-615-81879-0-9

A mú szerzői jogilag védett. Minden jog, így különösen a sokszorosítás, terjesztés és fordítás joga fenntartva. A mű a kiadó írásbeli hozzájárulása nélkül részeiben sem reprodukálható, elektronikus rendszerek felhasználásával nem dolgozható fel, azokban nem tárolható, azokkal nem sokszorosítható és nem terjeszthetô. 
Szerzők

Lektorok

Lectori Salutem!

Tanulmányok

Christián László - Lippai Zsolt: Kakukktojás vagy új rendészeti alappillér?

Gonda Éva: Az Europol hospitáció hasznosítása a pénzügyi nyomozók képzése terén

Kakócz Krisztián - Vedó Attila: A toloncolás szabály- és szervezetrendszere a második világháború előtt

Kovács Gábor: A vezetői kompetenciák fejlesztésének lehetőségei a Rendészettudományi Kar hallgatóinak körében

Magasvári Adrienn: Egy új jogviszony „születése” - az adó- és vámhatósági szolgálati jogviszony vizsgálata ..

Molnár Katalin: Mi harminc? Tudománymetria helyett - Szerzőtársas játék................................ 87

Nyeste Péter: A modern bűnügyi hírszerzés modelljeinek fejlődése ............................................ 103

Pajor Andrea: Adóigazgatási tisztviselők képzése .

Sallai János - Borszéki Judit: Egy megvalósítható utópia? Közös munkanyelv keresése a nemzetközi rendőri együttmúködés kezdetén.

Suba László: Nyelvhelyesség a közszférában: Létkérdés vagy úri huncutság?

Szabó Andrea - Hájer Tamara: A vámfelsőoktatás uniós elismerési eljárásának elemei

Szlifka Gábor: Okos adózás, okos adóigazgatás - Minden ami okos, de mit is jelent pontosan?

Kutatási eredmények

Balla József - Kiss Lajos: A rendvédelmi szervező szakirányú továbbképzési szak indításának legfontosabb tapasztalatai.

Borzán Anita - Szekeres Bernadett: A digitalizáció hatása a gazdasági szakismeretek és a számvitel oktatására.

Duchon Jenő: Tanulási stílus és játékos típus összevetése felnőtteknél, az oktatási folyamat játékosítása céljából

Erdős Ákos - Somogyi Ágnes: Koffeinhasználat és koffeinhasználati zavar vizsgálata rendészeti hallgatók körében

Halasi Nóra: Feltáró kutatás a hivatástudat és motiváció jelentőségének vizsgálatára, a Hajdú-

Bihar Megyei Adó- és Vámigazgatóság személyi állományának összefüggésében 251 


\title{
Duchon Jenő*: Tanulási stílus és játékos típus összevetése felnőtteknél, az oktatási folyamat játékosítása céljából
}

\begin{abstract}
Absztrakt
Mindenki rendelkezik valamilyen tanulási stílussal, amely meghatározza, hogy az adott személy milyen módon sajátít el új ismereteket. Ugyanakkor, ehhez hasonló módon mindenkit más dolog motivál egy játékon belül. A 2021-es év elején kérdőíves kutatás történt, amelynek keretében a Kolb-féle tanulási stílus kérdőív - Peter Huney és Alan Mumford által egyszerűsített változata -, illetve a Richard Bartle-féle játékos típus teszt került felhasználásra. A kérdőív célja az volt, hogy a kapott válaszok segítségével felmérjük, van-e kapcsolat az egyes tanulási stílusok és a különböző játékos típusok között, lehetővé téve ezáltal, hogy az oktatási folyamatokban alkalmazott játékosítási módszerek és eszközök felhasználása minél hatékonyabb lehessen. Jelen tanulmány a felmérés első eredményeit ismerteti.
\end{abstract}

Kulcsszavak: tanulási módsæ̧erek, gamifikáció, fókuszcsoport

\begin{abstract}
Each person has a learning style that determines how the person learns new knowledge. However, for similar this, everyone is motivated by different things within a game. A questionnaire-based survey was constructed in early 2021. This survey used both a simplified version of Kolb's learning style questionnaire by Peter Huney and Alan Mumford and Richard Bartle's player type test. The questionnaire aimed to measure that: are there any relationships between each learning style and different types of players. If we find any connection between categories of learning styles and sorts of player types, the results benefit the gamification of the learning process. This study publishes the first results of the survey. Overall, in addition to individual-level competencies, it is crucial whether openness to digital transformation appears at the level of those working in the economic field. If so, how fast are the efforts and response time to introduce digital trends? In our view, if we respond to change on time, accounting education will not be a victim of digitization but a winner.
\end{abstract}

Keywords: learning methods, gamification, focus group

\section{Elméleti alapok}

Számtalanszor tapasztalhatjuk, amikor a játékokra terelődik egy beszélgetésen belül a szó, hogy nagyon sokan nem értik, miként lehet komolytalan, gyerekes dolgokat ennyire komolyan venni. Sokszor szembesülünk azzal, hogy játszani csak a gyerekek játszanak, a felnőttek kizárólag komoly dolgokkal foglalkoznak. Ez a vélekedés ugyanakkor hibás. Különösen, ha figyelembe vesszük, hogy a játékok az egyik legnagyobb bevételt produkáló

\footnotetext{
* Duchon Jenő, OTP Bank Nyrt., képzési szenior tanácsadó, https://orcid.org/0000-0001-6931-2828, jeno.duchon@otpbank.hu
} 
szórakoztatóipar részévé váltak. A 2019-es évben a kizárólag digitális, interaktív játékokra épülő játékipar 109,4 milliárd dollár bevételt produkált ${ }^{543}$.

Látható tehát, hogy szeretünk játszani azért, mert a játékok olyan mechanizmusokat indítanak be az emberi viselkedésben, amelyek örömérzést okoznak, és motiválnak az adott tevékenység végrehajtására. Ugyanakkor nem szükséges játszanunk ahhoz, hogy ugyanezek a mechanizmusok beinduljanak. Elegendő, ha „kölcsönvesszük” a játékoktól azokat az elemeket, amelyek kiváltják a játékosokból ezeket a pozitív, ösztönző érzéseket. Az egyes folyamatok játékosítása (gamifikálása) pontosan erről szól, még akkor is, ha a szakirodalomban többféle definíciót is találunk, hogy csak néhányat említsünk:

- Játékelemek és játéktervezési technikák használata játékon kívüli környezetben. ${ }^{544}$

- A játékosítás egy átfogó kifejezés arra az esetre, amikor a videó játék elemeket a felhasználói élmény, illetve a felhasználói elkötelezettség érdekében használják fel játékon kívüli szolgáltatásokban és alkalmazásokban. ${ }^{545}$

- A játékalapú múködési elvek, a játékesztétikai és a játéktervezői gondolkodás használata az emberek lekötésére, cselekvésre sarkallására, a problémák megoldására és a tanulás elősegítésére. ${ }^{546}$ (Kapp, 2012)

A fentieken túl számos más értelmezés is létezik, de a legutóbbi rávilágít arra, hogy a tanítástanulás folyamatában is alkalmazható a játékosítás. Ugyanakkor fontos megjegyezni, hogy egy tanulási folyamat játékosítása semmiképpen nem jelenti azt, hogy játékot készítünk az oktatás során. A különbség megértése érdekében célszerű megvizsgálnunk a Deterding modellt. ${ }^{547}$

\footnotetext{
543 SuperData, A Nielsen Company. 2020. 2019 Year in Review - Digital Games and Interactive media. SuperData, A Nielsen $\quad 2020 . \quad$ https://direc.ircg.ir/wpcontent/uploads/2020/01/SuperData2019YearinReview.pdf (Letöltve: 2021. március 29.)

544 WerbaCH, Kevin - Hunter, Dan: For the Win: How Game Thinking Can Revolutionize Your Business. Wharton Digital Press, Philadelphia, 2012.

545 DETERDING, Sebastian et al.: Gamification. Using game-design elements in non-gaming contexts. In: CHI '11 Extended Abstracts on Human Factors in Computing Systems (CHI EA '11). Association for Computing Machinery, New York, 2011. pp. 2425-2428. https://doi.org/10.1145/1979742.1979575

${ }^{546}$ KAPP, Karl M.: The gamification of learning and instruction: game-based methods and strategies for training and education, Pfeiffer, San Francisco 2012.

${ }^{547}$ Deterding, Sebastian et al.: From Game Design Elements to Gamefulness: Defining “Gamification”. In: Proceedings of the 15th international academic MindTrek conference: Envisioning future media environments 2011.
} 
Irányított játék (game)

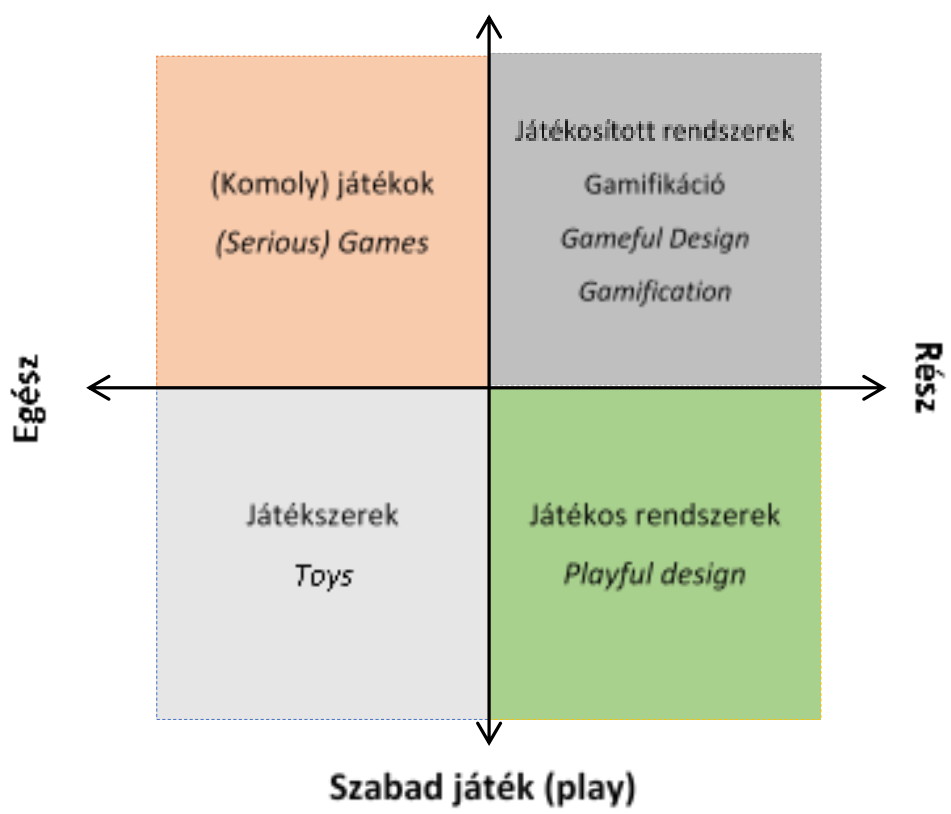

1. ábra Deterding-féle játékfelosztás

Az 1. ábra felső fele azokat a tevékenységeket tartalmazza, amelyek irányítottak, szabályozottak és célrendszerük strukturált. Az ábra alsó része pedig azokat a tevékenységeket mutatja be, amelyeket mindenféle kötöttség nélkül, szabadon végezhetünk. A függóleges elválasztó vonaltól balra találjuk azokat a tevékenységeket, ahol a játéknak az egésze kerül felhasználásra, míg jobbra azokat, ahol annak csak egyes részeit alkalmazzuk. Láthatjuk, hogy játékosítás esetén a tevékenység szabályozott, keretek között tartott, de semmiképpen sem igazi játék, hiszen annak csak egyes részei kerülnek beültetésre az adott tevékenységbe.

Ahhoz, hogy megértsük miért érdemes a játékosítanunk a képzést, a képzési folyamatokat, érdemes megvizsgálnunk, hogy Werbach és Hunter miként osztja fel a játékosítást három területre: 548

- Belsö gamifikáció: Egy szervezet belső életét, munkafolyamatait, múködését segítő játékosítás a hatékonyság növelése érdekében.

- Külsố gamifikáció: A szervezeten kívüli ügyfelekre, fogyasztókra irányuló játékosítás. Ebben az esetben a cél a meggyőzés, a bevonódás biztosítása, új fogyasztók megszerzése.

- Viselkedésmódositó gamifikáció: Ebben az esetben a játékosítás célja, hogy attitűdváltozást érjünk el a folyamatba bevont személyek esetén.

Amennyiben képzésről beszélünk, úgy mind a hatékonyságnövelés (pl. a képzésben résztvevők munkafolyamatait szeretnénk hatékonyabbá tenni), mind a meggyőzés és bevonódás (pl. a képzésben résztvevők bevonása), és nem utolsó sorban a

548 Werbach, Kevin - Hunter, Dan: For the Win: How Game Thinking Can Revolutionize Your Business. Wharton Digital Press, Philadelphia, 2012. 
viselkedésváltoztatás (pl. tanulók a tanuláshoz, az adott ismerethalmazhoz történő hozzáállásának megváltoztatására) elérése cél lehet.

A képzés játékosításával, tehát mindenképpen érdemes foglalkoznunk. Hosszú távon csak akkor tartható fenn egy játékosított rendszer, ha megfelelően adaptív módszereket alkalmazunk, ezek a metódusok pedig okkal kerülnek be az adott rendszerbe. A képzések során, emiatt vizsgáljuk minden esetben a tanulók tanulási stílusát, a játékfejlesztő cégek ugyanezen okokból foglalkoznak a játékosok attitűd vizsgálatával. A cél mindkét esetben tehát olyan mechanizmusok, technikák alkalmazása, melyek segítségével az adott rendszer hatékonysága növelhető, a bevonódás elősegíthető és akár attitűd változás is elérhető. Ezzel pedig visszatértünk a játékosítás három színteréhez.

A fentiek alapján joggal merülhet fel, mi lehet az összefüggés az egyes személyek tanulási stílusa, és az adott személy játékos attitúdje között. Feltételezhető, hogy mindkét esetben hasonló motivációs erők hajtják a személyt az adott tevékenységen belül, legyen az a tevékenység, a tanulás vagy a játék. Feltételezhetjük például, hogy azok, akik szívesen tanulnak közösségben, azok a játékon belül is szociális attitúddel rendelkeznek, vagy mindazok, akik a tanulás során aprólékosan megterveznek mindent, hasonló attitúdöt mutatnak a játékokon belül is.

Jelen kutatás célja volt, hogy felmérje a felnőttek tanulási stílusát, és összevesse azt a játékos attitűdjükkel, kapcsolatot keresve az egyes változók között. Amennyiben ugyanis találunk kapcsolatot, úgy az egyes tanulási stílusokat támogató módszerek kiegészíthetôvé válnak az egyes játékos típusokat célzó játék mechanizmusokkal, lehetővé téve ezáltal komplexebb játékosított képzési folyamatok fejlesztését.

\section{Az egyén tanulási stílusának feltérképezése}

Minden tanulás valójában egy jól megtervezett akcióterv, amely valamilyen stratégia szerint történik. Ezen stratégia célja, hogy az adott tanuló a lehető leghatékonyabban legyen képes elsajátítani egy adott ismerethalmazt. ${ }^{549}$ Minden személy saját, preferált tanulási stratégiával rendelkezik, ugyanakkor az adott helyzethez igazodó stratégiát az egyéni jellemzőkön túl, a tanítás-tanulás folyamatában alkalmazott módszerek, munkaformák és taneszközök is befolyásolják. Jól látható tehát, hogy a stratégia kialakításában jelentős szerepet játszik maga a tanuló személye, aki számos stratégiai mintát alakít ki, hogy munkája a leghatékonyabb legyen az adott képzési folyamatban. Ezeket az egyénre jellemző, preferált mintákat értjük tanulási stílus alatt. Meg kell jegyezni, hogy számos tanulási stílussal foglalkozó elmélet létezik, mindegyik közös vonása, hogy egy többdimenziós skálán határozza meg az adott személy jellemző értékeit, és kategóriákat alkotnak. Ugyanakkor, egyik elmélet sem skatulyázza be a személyeket egyik vagy másik kategóriába. ${ }^{550}$

A felnőttek tanulási stílusának felmérése a Kolb-féle kérdőív Peter Huney és Alan Mumford által egyszerűsített modellje segítségével történt. A kitöltőnek 80 egyszerű állításról kellett eldönteni, hogy az jellemző rá vagy sem. A modell négy alapstílust határoz meg, megadva

\footnotetext{
${ }^{549}$ GASKÓ Krisztina et al.: Hatékony tanulás, Bölcsész Konzorcium, Budapest, 2006.

${ }^{550}$ TóTH Péter: Tanulási stílus vizsgálata a szakképzésben. Empirikus kutatások a szakmai pedagógusképzésben. DSGI Ergonómiai Mérnöki Iroda Kft, Budapest, 2013, p. 78.
} 
azokat a tulajdonságjegyeket, amelyek azokra a személyekre jellemzőek, akiknél az adott alapstílus erőteljesen megjelenik. A négy alapstílus és azok jellemzői az alábbiak ${ }^{551}$ :

- Tevékeny alapstílus: Az ilyen személyeket a tapasztalás élménye hajtja. Minden esetben nyitottak az újdonságokra, és feltételek nélkül belevetik magukat a tanulásba. Ugyanakkor nehezen bírják a monoton, hosszú és precíz munkát igénylő tanulást, viszont szívesen tanulnak közösségben, kedvelik a csoportmunkát.

- Töprengó alapstílus: Minden feladatot mérlegelnek. Tanulásukban jelentős szerepet kap az adatgyüjtés, melyet ezt követően kiértékelnek. A precíz és megfontolt döntések rendkívül fontosak a számukra. Értékelő munkájuk része, hogy mások véleményét is meghallgassák és figyelembe vegyék döntéseik során.

- Elméleti alapstílus: Az elméleti stílussal jelentős mértékben bíró személyek modellekben gondolkodnak. Ennek köszönhetôen sok esetben a felmerülő problémát képesek elemi lépésekre bontva elemezni. A modellek konkrét megvalósításának mikéntje számukra már nem annyira fontos. A modellező gondolkodásuk előnye, hogy a felmerülő új ismereteket könnyedén kapcsolják saját ismerethálójukba, tudásrendszerükbe.

- Gyakorlati alapstílus: Az erősen gyakorlati stílussal rendelkező személyek szeretnek minden elméletet kipróbálni a gyakorlatban. Szükség szerint képesek a gyors döntéshozatalra. Preferálják a végrehajtható tevékenységeket, és az azok végrehajtásából származó haszon fontos motiváló tényező a számukra.

A négy alapstílust 2-2 párra bonthatjuk: Tevékeny/Töprengő illetve Elméleti/Gyakorlati. Ezen párokból várhatóan az egyik erősebben érvényesül az adott személyben. Ennek mértéke az alábbiak szerint könnyen kalkulálható:

y = Gyakorlati pontérték - Elméleti pontérték

$\mathrm{x}=$ Töprengő pontérték - Tevékeny pontérték

A kapott x és y érték alapján megállapítható valakiről, hogy mennyire van jellemző, preferált stílusa:

Nincs preferált stílus: $|\mathrm{x}| \leq 5$ és $|\mathrm{y}| \leq 5$

Közepesen preferált stílus: $5<|\mathrm{x}| \leq 12$ vagy $5<\mid$ y $\mid \leq 12$

Erôsen preferált stílus: $12<|\mathrm{x}| \leq 20$ vagy $12<|\mathrm{y}| \leq 20$

\section{Az egyén játékos típusának meghatározása}

Mivel a korábbi fejezetben vázolt modell négy dimenzió mentén határozza meg egy adott személy tanulási stílusát, ezért jól összevethető hátteret biztosít a Bartle-féle játékos-felosztás modellel történő összevetéséhez, amely szintén négy kategóriát határoz meg a játékosok identitása alapján ${ }^{552}$ :

- Gyilkosok (Killers): Számukra a legfontosabb cél a többi játékos legyőzése. A győzelem történhet magányosan vagy csapattagokkal összedolgozva. Motivációjukat a játék kompetitív elemeiből nyerik.

\footnotetext{
${ }^{551}$ KISS László:. A hallgatók tanulási stílusa. SPECTRUM Mérnökiroda, 2020. http://www.spec.hu/tanulstilus.htm (Letöltve: 2021. március 29.)

552 BARTLE, Richard: "Hearts, clubs, diamonds, spades: Players who suit MUDs." Journal of MUD research, 1996/1. szám. p. 19.
} 
- Eredményközpontúak (Achievers): A legfontosabb cél, hogy a játékon belül fellelhető összes feladatot tökéletesen megoldják. Minden kihívással, problémával addig próbálkoznak, amíg annak megoldása nem sikerül 100\%-osan, nem szerzik meg a feladatokért járó összes jutalmat. Nagyon motiválják őket a játékon belül gyújthető elemek. Fontos számukra a játékon belüli státuszuk, elvárják, hogy játékon belüli rangjukat, eredményeiket mások is láthassák.

- Kapcsolatépitók (Socializers): Ezen játékosok számára a játék csak egy platform a másokkal történő kapcsolattartásra, kapcsolatépítésre. Éppen ezért szívesen kooperálnak másokkal, szeretik a csoportmunkát. Szívesen segítenek másoknak, a játékon belül empatikusak.

- Felfedęốk (Explorers): A játékra egy utazásként tekintenek. Céljuk a játék részleteinek felfedezése, annak minden elemének megtapasztalása. Szívesen próbálgatják a játék által kínált opciókat. Céljuk a háttérben húzódó mechanikák megértése, feltérképezése. Szívesen feszegetik a játékszabályok kereteit annak érdekében, hogy megértsék a játék világának múködési logikáját. Alapvetően önvezérelten fedezik fel a világot. Később szívesen alkotnak új pályákat, adnak hozzá új elemeket az adott játék világához.

Természetesen, akárcsak a tanulási stílusok esetén, itt sem lehet egy személyt beskatulyázni egyetlen típusba. Minden személyben rejtőzik egy „gyilkos”, egy „eredményközpontú”, egy „kapcsolatépítő” és egy „felfedező” játékos-én, azonban ezek a játékos személyiségek erőssége mindenkinél eltérő lesz.

\section{A minta jellemzése}

A kérdő́ivet összesen 117 fő töltötte ki az első felkérést követően, melyből 60 fő férfi és 57 fő nő volt. Amennyiben a végzettség szerint vizsgáljuk a mintát megfigyelhető, hogy túlnyomórészt felsőfokú végzettségűek jeleztek vissza a felhívásra (2. ábra).

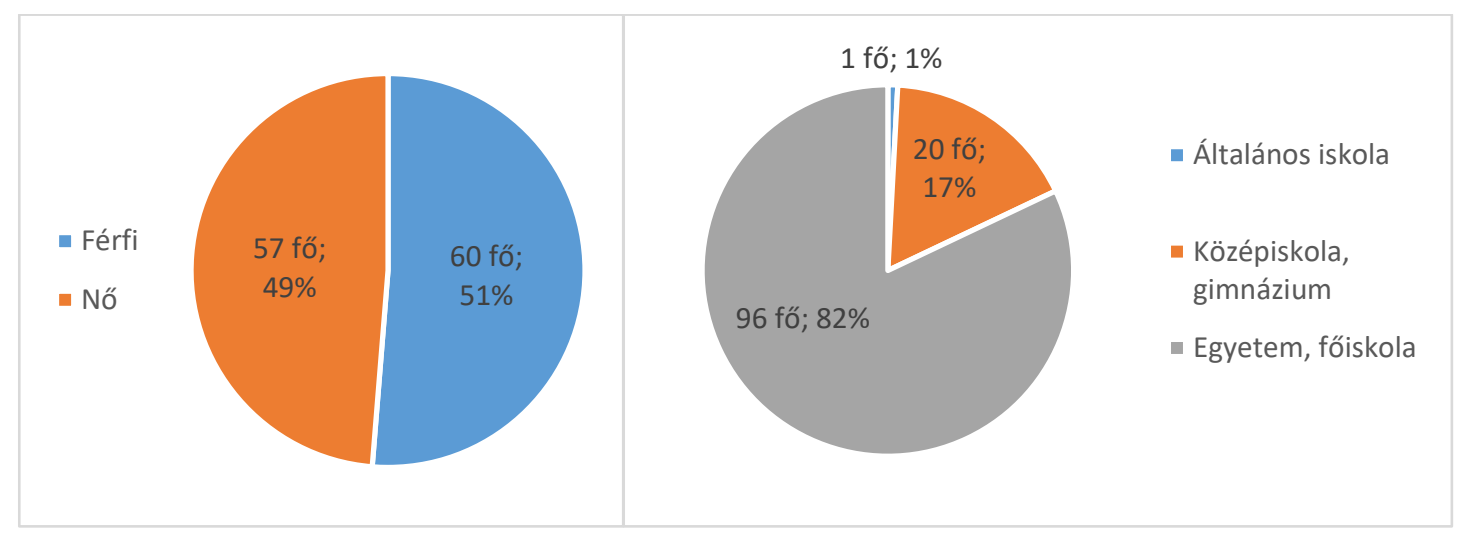

2. ábra A kérdőív kitöltőinek nem, illetve végzettség szerinti eloszlása

Amennyiben a kitöltôk életkorát vizsgálva láthatjuk, hogy a legfiatalabb kitöltő 23 éves, míg a legidősebb kitöltő 68 éves volt. Ennek ellenére a válaszadók majdnem fele (45,3\%), 40 és 50 év közé tehető (3. ábra). 


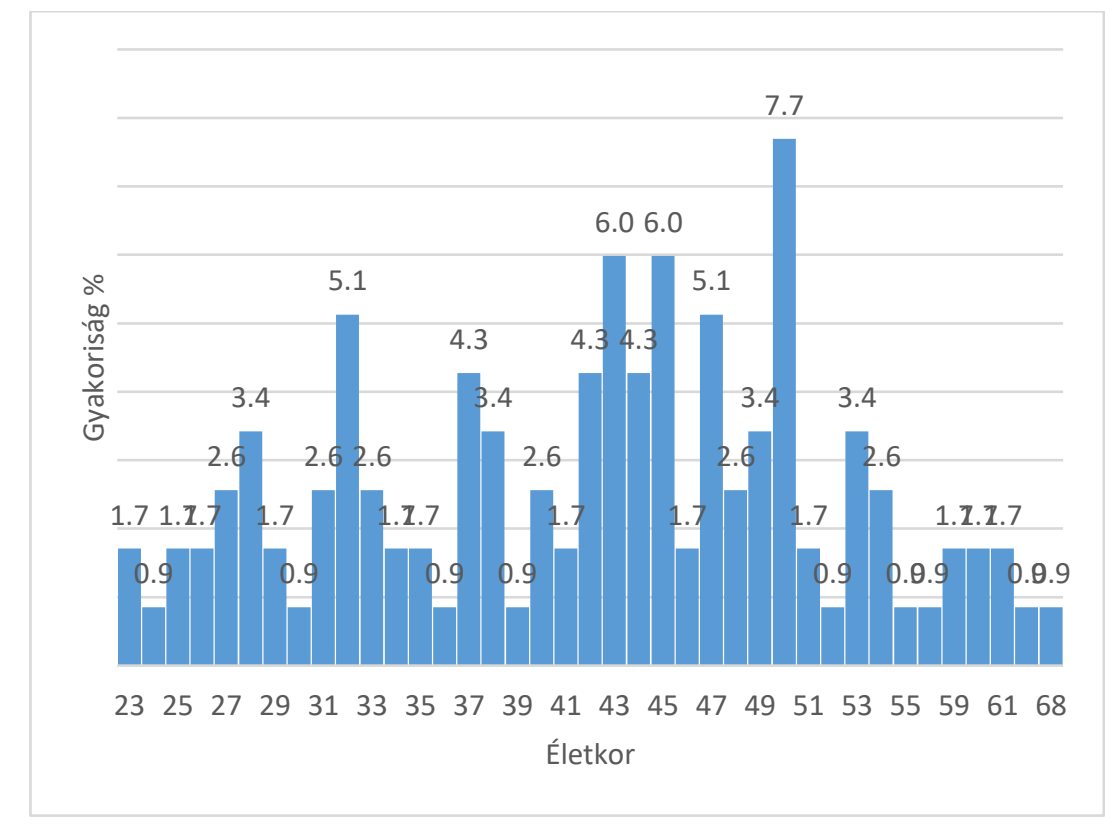

3. ábra A kérdőív kitöltőinek kor szerinti eloszlása

\section{Tanuláshoz és játékhoz használt eszközök összevetése}

A felmérés során megvizsgálásra került, hogy a tanulók milyen gyakran használnak valamilyen információs technológiára épülő eszközt a tanuláshoz, illetve játék céljából (4. ábra). Az alábbi ábrán az egyes felhasználási gyakoriságok a tanulás és a játék közötti párban kerülnek megjelenítésre, minden esetben előbb a tanulásra használt eszközhasználat gyakorisága, majd ezt követően az eszköz játékra történő felhasználásának gyakorisága.

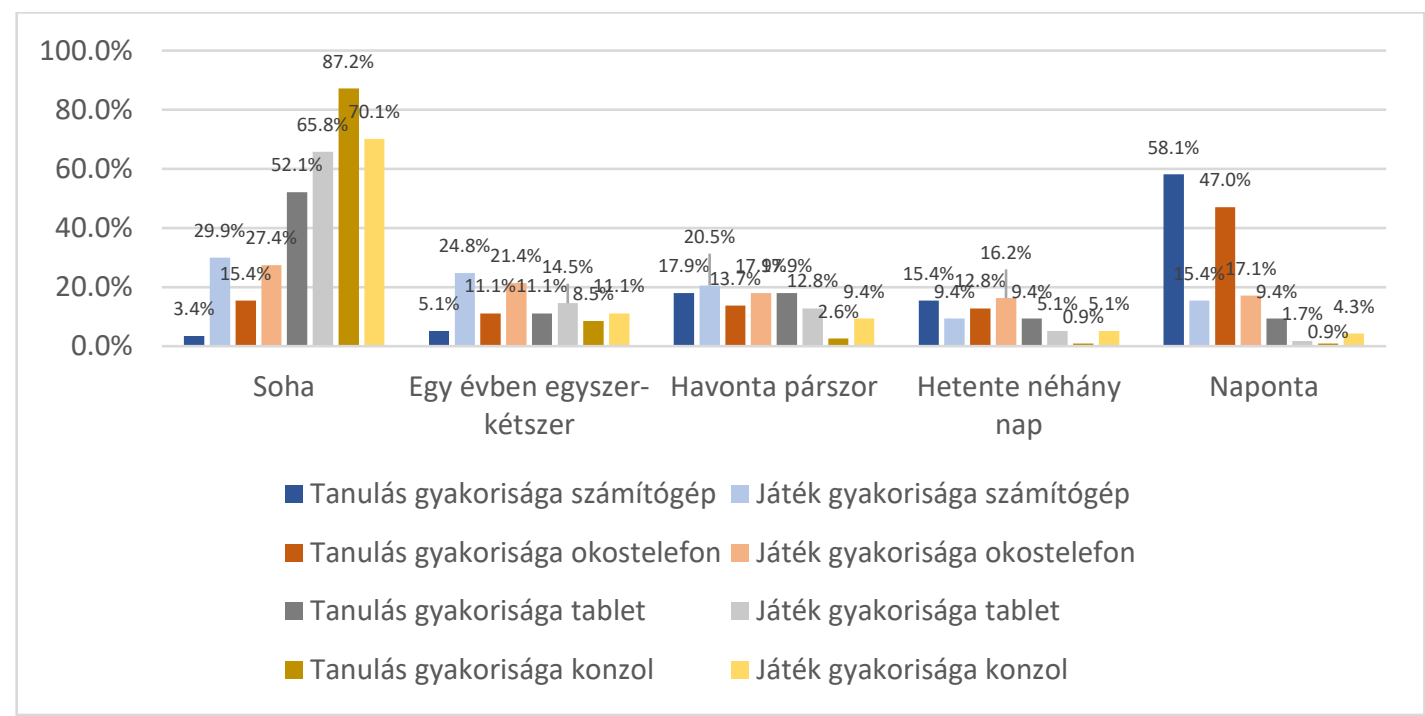

5. ábra A tanuláshoz, illetve a játékhoz használt IKT eszközök gyakorisága

Az eredményekből látható, hogy a válaszadók nagy része, majdnem fele naponta használja a számítógépét $(58,1 \%)$ illetve az okos-telefonját $(47 \%)$ tanulásra. Hasonló mértékű gyakoriság nem fedezhetô fel a kitöltők részérôl a játék célú felhasználással kapcsolatban egyik eszköz tekintetében sem, bár az megfigyelhető, hogy szintén ez a két céleszköz a leggyakoribb az ilyen típusú elfoglaltság végzéséhez is. 


\section{A válaszadók tanulási stílusa}

A kérdőív kitöltôi esetén elemeztük, hogy a négy tanulási alapstílus mindegyikéhez tartozó kérdésekből (max. 20 darab) az adott illető mennyit jelölt meg, hogy az rá mennyire jellemző. Ezt követôen az így kapott értéket százalékra váltva láthatóvá válik, hogy az adott stílus mennyire jellemző az adott személyre. Ha az egyes stílusokon belül elért százalékértékeket (tanulási stíluserôsségi mutatókat) gyakoriságuk szerint grafikonon ábrázoljuk, láthatjuk, hogy az elméleti tanulási stílus nagyon sokaknál igen magas értéket ért el, míg a tevékeny stílus esetén egy sokkal laposabb, nagyobb eloszlású görbét kapunk, ahol a legmagasabb előfordulás (90\%) is csak 1 főnél tapasztalható. Ellentétben az elméleti stílussal, ahol ugyanez az érték 23 főnél szerepelt. Az 5. ábra tanulsága, hogy bár a gyakorlatias tanulók nagyobb számmal voltak jelen a kitöltésben, mégis a tevékeny - minden újdonságra nyitott - szemlélet még itt is elég alacsony lehet.

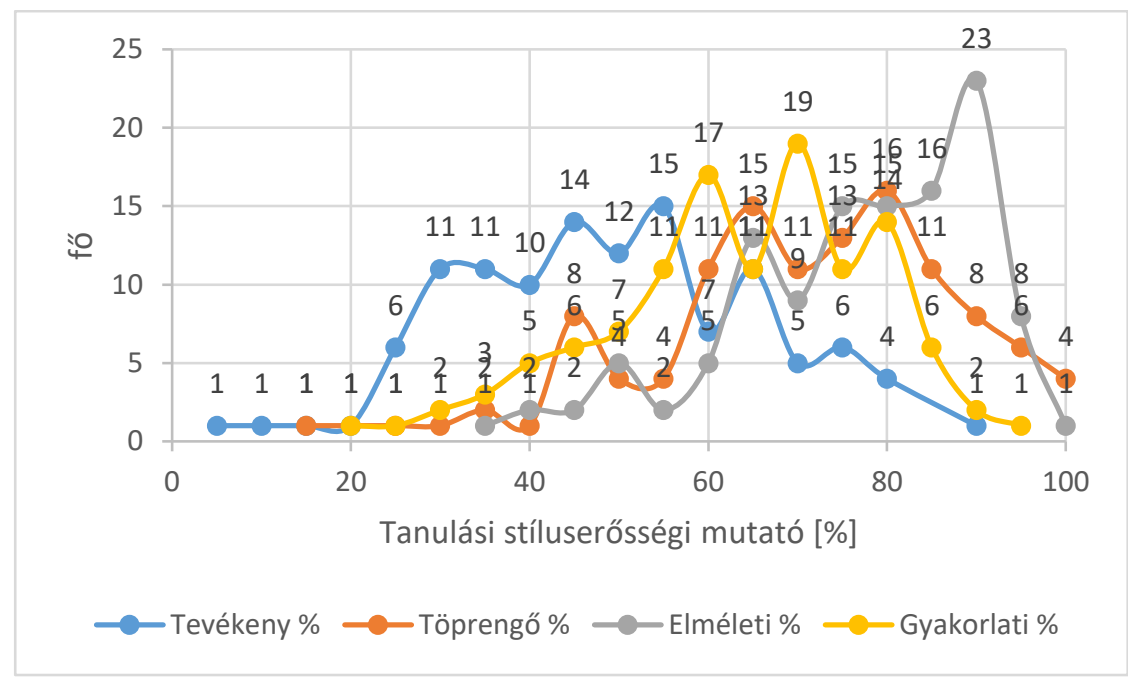

6. ábra A válaszadók tanulási stíluserősségi mutatóinak gyakorisága

Abban az esetben, ha összevetjük a tanulási stílus szerinti párokat - Tevékeny/Töprengő, illetve Elméleti/Gyakorlati -, és megvizsgáljuk, hogy a stíluspárok között melyek a preferáltabbak és azok milyen mértékben, szintén azt tapasztaljuk, hogy a legnagyobb gyakorisági adatok a Töprengő, illetve az Elméleti stílusoknál jelennek meg (6. ábra).

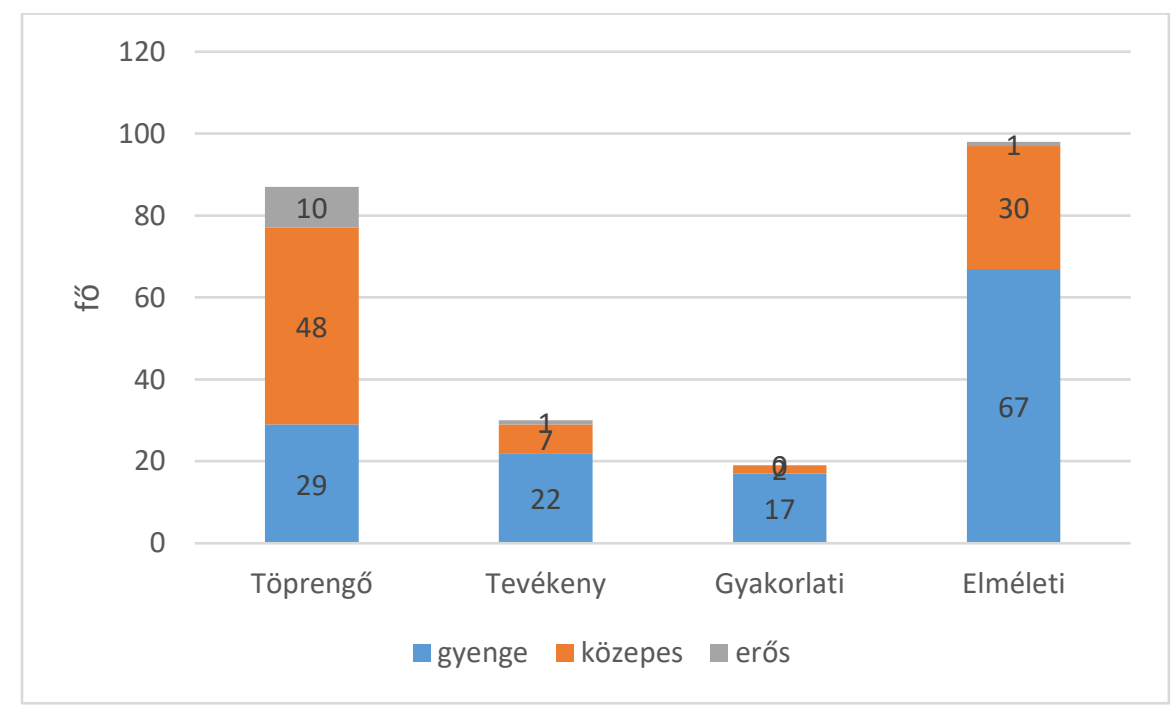

6. ábra A válaszadók preferált tanulási stílusának és annak erôsségének gyakorisága 


\section{A válaszadók játékos stílusa}

A Bartle-féle kérdőív esetén az egyes játékos típusokhoz adott számú válasz tartozik (Gyilkos és Kapcsolatépítő esetén 20, Eredményközpontú és Felfedező esetén 19 darab). Az egyes típusra adott válaszok száma és a típushoz tartozó összes válasz százalékos aránya adja meg mennyire erôs az egyes egyének esetén az adott játékos típus attitűd (játékos típus attitűd erôsségi mutatókat). Ha grafikonon ábrázoljuk az egyes játékos típusokhoz tartozó stíluserősségi mutatók gyakoriságát, akkor láthatjuk, hogy a válaszadók között alacsony a kompetitív szemlélet („Killer”), ezzel szemben a játékmechanikák megismerésére, a játék felfedezésére törekvő („Explorer”) személyek száma jelentős. Az eredményközpontú szemlélet („Achiever”) erőssége nem olyan magas a kitöltők között, viszont a görbe csúcsossága jelzi, hogy a kitöltők elég egységesek ezen a téren, ellentétben a közösségi szemlélettel („,Socializer”), amely a leglaposabb görbe a négy közül (7. ábra).

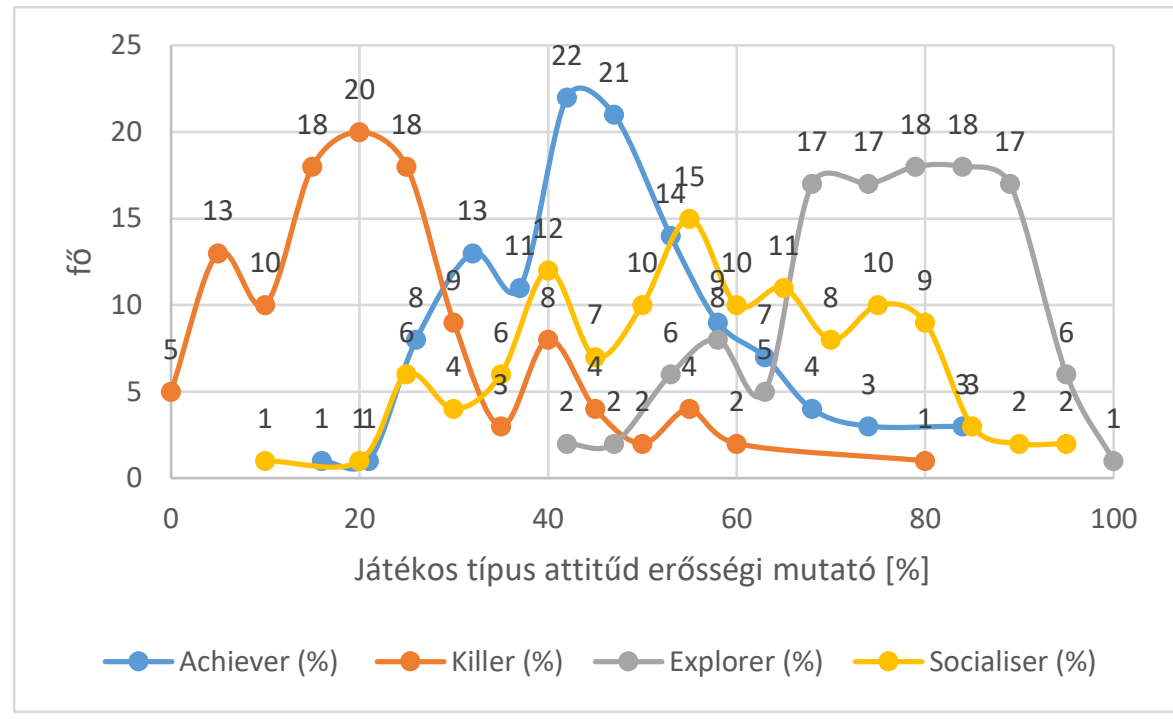

7. ábra A válaszadók játékos típus attitűd erősségi mutatóinak gyakorisága

Az egyének tanulási stílus erôsségét jelző változóinak és játékos típus attitűdjének erősségét jelző változóinak korreláció vizsgálata

Korrelációs vizsgálattal került felderítésre az egyes tanulási stílusok, illetve játékos típusok közötti kapcsolat erőssége és iránya. Előbb a tanulási stílusok erősségét mutató változók között, majd a játékos attitűd erősségét jelző mutatók közötti korrelációs együtthatók kerültek meghatározásra, ezt követően pedig a két vizsgált kategória változói kerültek összevetésre.

A korreláció vizsgálat előtt az egyes változókon Kolmogorov-Smirnov próba segítéségével ellenôrizésre került, hogy az adott mintáink normál eloszlásúak-e (1. táblázat).

\begin{tabular}{|l|l|l|l|l|l|l|l|l|}
\hline & $\begin{array}{l}\text { Tevé- } \\
\text { keny }\end{array}$ & $\begin{array}{l}\text { Töpren- } \\
\text { gó }\end{array}$ & $\begin{array}{l}\text { Elmé- } \\
\text { leti }\end{array}$ & $\begin{array}{l}\text { Gyakor- } \\
\text { lati }\end{array}$ & Achiever & Killer & Explorer & Socializer \\
\hline $\begin{array}{l}\text { Kolmogorov- } \\
\text { Smirnov Z }\end{array}$ &, 768 & 1,084 & 1,469 & 1,293 & 1,409 & 1,763 & 1,343 &, 799 \\
\hline $\begin{array}{l}\text { Szignifikancia } \\
\text { szint (P) }\end{array}$ &, 597 &, 191 &, 027 &, 070 &, 038 &, 004 &, 054 &, 546 \\
\hline
\end{tabular}

1. táblázat: Kolmogorov-Smirnov próba eredménye 
A próba alapján látható, hogy egyedül az elméleti tanulási stílus erôssége változó, illetve a gyilkos játékostípus attitűd erősségét jelző változó eloszlása normáleloszlású. Ugyanakkor, amennyiben figyelembe vesszük azt a tapasztalati úton szerzett szabályt, mely szerint a csúcsosság és a ferdeség nem lehet $|1|$-nél több, illetve a csúcsosság standard hibája és a ferdeség standard hibája abszolútértékben nem haladja meg a 2,58, szigorúbb esetben az 1,96 értéket, úgy az adott változókon alkalmazhatók a paraméteres próbák, annak ellenére is, hogy nem teljesen normáleloszlásúak. Ennek megfelelően a változóinkon elvégezhető a Pearson korrelációs vizsgálat ${ }^{553}$ (2. táblárat).

\begin{tabular}{|l|l|l|l|l|l|l|l|l|}
\hline & $\begin{array}{l}\text { Tevé- } \\
\text { keny }\end{array}$ & $\begin{array}{l}\text { Töpren- } \\
\text { gó }\end{array}$ & $\begin{array}{l}\text { Elmélet } \\
\mathrm{i}\end{array}$ & $\begin{array}{l}\text { Gyakor- } \\
\text { lati }\end{array}$ & $\begin{array}{l}\text { Achi- } \\
\text { ever }\end{array}$ & $\begin{array}{l}\text { Kille } \\
\text { r }\end{array}$ & $\begin{array}{l}\text { Explo- } \\
\text { rer }\end{array}$ & $\begin{array}{l}\text { Sociali- } \\
\text { zer }\end{array}$ \\
\hline $\begin{array}{l}\text { Ferdesé } \\
\text { g }\end{array}$ &, 014 &,- 606 &,- 813 &,- 508 &, 534 &, 975 &,- 530 &,- 092 \\
\hline $\begin{array}{l}\text { Ferdesé } \\
\text { g std } \\
\text { hibája }\end{array}$ &, 224 &, 224 &, 224 &, 224 &, 224 &, 224 &, 224 &, 224 \\
\hline $\begin{array}{l}\text { Csúcsos } \\
\text {-ság }\end{array}$ &,- 336 &, 312 &, 148 &,- 047 &, 375 & 1,150 &,- 262 &,- 575 \\
\hline $\begin{array}{l}\text { Csúcsos } \\
\text {-ság std. } \\
\text { hibája }\end{array}$ &, 444 &, 444 &, 444 &, 444 &, 444 &, 444 &, 444 &, 444 \\
\hline
\end{tabular}

2. táblázat A tanulási stílus erősségét jelzô változók és a játéktípus attitűd erôsségét jelzô változók ferdesége és csúcsossága

\begin{tabular}{|ll|}
\hline Korrelációs együttható értéke & Korrelációs kapcsolat erőssége \\
\hline $\mathbf{r}=|\mathbf{1}|$ & Tökéletes kapcsolat \\
\hline$|\mathbf{1}|>\mathbf{r}>=|\mathbf{0 , 7}|$ & Erôs kapcsolat \\
\hline$|\mathbf{0 , 7}|>\mathbf{r}>=\mid \mathbf{0 , 3}$ & Közepes kapcsolat \\
\hline $\mathbf{0 , 3}>\mathbf{r}>=\mathbf{0}$ & Gyenge kapcsolat \\
\hline $\mathbf{r}=\mathbf{0}$ & Nincs kapcsolat \\
\hline 3. táblázat Korrelációs együtthatók értelmezése a kapcsolat erőssége szerint jelen tanulmányon belül.
\end{tabular}

Első körben vizsgáljuk meg, mennyire korrelálnak egymással a tanulási stílusok erősségét mutató változók (3. táblázat). Láthatjuk, hogy igazán erős korreláció egyik változópár esetében sem jelentkezett, ugyanakkor erősen közepes korreláció a Tevékeny-Töprengő $(\mathrm{r}=-0,445)$ illetve Töprengő-Elméleti $(\mathrm{r}=0575)$ változópárok esetén tapasztalható (4. táblázat). Mindkettő pár esetében a Töprengő stílus megjelenik közös elemként.

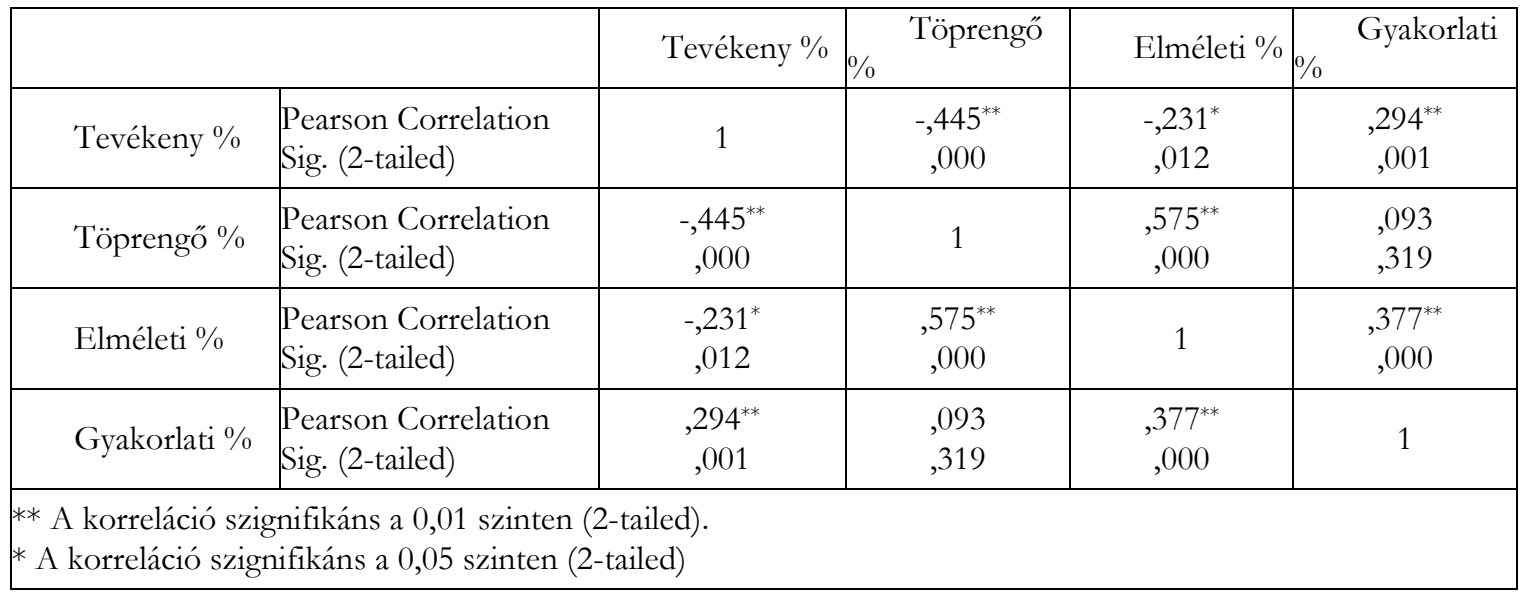

4. táblázat Tanulási stílus erősségét jelző változók korrelációja

553 SAjTOS László és MiTEV Ariel. 2007. SPSS Kutatási és adatelemzési kézikönyv. Alinea Kiadó, Bp., 2007. 
Figyelembe véve, hogy a Töprengő tanulási stílus az egyik leggyakrabban megjelenő preferált tanulási stílusa a válaszadóknak (lásd 6. ábra A válaszadók preferált tanulási stílusának és annak erösségének gyakorisága), ráadásul itt a leggyakoribb a közepesen preferált érték, célszerünek mutatkozik a képzések során ezt a stílust támogató módszereket alkalmazni, összehangolva az Elméleti stílust támogató módszerekkel. Ugyanakkor a fordított korreláció miatt azt láthatjuk, hogy azon válaszadók esetén, akiknél a Tevékeny stílus erôs értékként jelentkezik, ott a Tevékeny stílus várhatóan alacsony mértékű lesz. Ilyenkor a Tevékeny stílushoz tartozó módszerek elképzelhető, hogy ellentétes hatást váltanak ki.

A következő körben a játéktípus attitűd erősségi mutatóinak korrelációját vizsgáltuk (5. táblázat). Jól látható, hogy itt is inkább erősen közepes erősségủ korrelációt találunk, ám ezek mindegyike fordított korreláció, azaz ahol az egyik változó értéke a válaszadónál magas volt, ott a másik változó értéke inkább alacsonyabbnak bizonyult. Az alábbiak szerint tehát, azok, akik Eredményközpontúak, várhatóan kevésbé törődnek a játékostársaikkal, kevésbé fontosak számukra a játékon belüli emberi kapcsolatok $(r=-0,600)$. Kicsivel alacsonyabb fordított korrelációs értéket kapunk a kompetitív játékstílust előnyben részesítők esetén, a közösségi játékos attitűddel szemben $(r=-0,543)$. A mutató egyértelműen jelzi, hogy az ilyen típusú játékosok esetében a versengő szellemben az egyén fontosabb tényező (saját maguk), mint a közösség, még akkor is, ha csapatban dolgoznak, hiszen ekkor is az a lényeg, hogy ők a győztes csapat tagjai legyenek. Szintén a kompetitív játékosoknál jelenik meg egyértelmúen korrelációs kapcsolat a felfedező játékos attitűddel szemben $(r=-0,442)$

\begin{tabular}{|c|c|c|c|c|c|}
\hline & & Achiever $\%$ & Killer \% & Explorer \% & 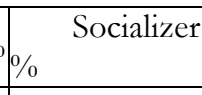 \\
\hline Achiever $\%$ & $\begin{array}{l}\text { Pearson Correlation } \\
\text { Sig. (2-tailed) }\end{array}$ & 1 & $\begin{array}{l}, 002 \\
, 979\end{array}$ & $\begin{array}{l}-, 167 \\
, 072\end{array}$ & $\begin{array}{c}-, 600 * * \\
, 000\end{array}$ \\
\hline Killer \% & $\begin{array}{l}\text { Pearson Correlation } \\
\text { Sig. (2-tailed) }\end{array}$ & $\begin{array}{l}, 002 \\
, 979\end{array}$ & 1 & $\begin{array}{c}-, 442^{* *} \\
, 000\end{array}$ & $\begin{array}{c}-, 543 * * \\
, 000\end{array}$ \\
\hline Explorer \% & $\begin{array}{l}\text { Pearson Correlation } \\
\text { Sig. (2-tailed) }\end{array}$ & $\begin{array}{l}-, 167 \\
, 072\end{array}$ & $\begin{array}{c}-, 442^{* *} \\
, 000\end{array}$ & 1 & $\begin{array}{l}-, 180 \\
, 052\end{array}$ \\
\hline Socializer $\%$ & $\begin{array}{l}\text { Pearson Correlation } \\
\text { Sig. (2-tailed) }\end{array}$ & $\begin{array}{c}-, 600 * * \\
, 000\end{array}$ & $\begin{array}{c}-, 543^{* *} \\
, 000\end{array}$ & $\begin{array}{l}-, 180 \\
, 052\end{array}$ & 1 \\
\hline
\end{tabular}

\section{5. táblázat Játéktípus attitűd erősségét jelző változók korrelációja}

Végül összevetésre kerültek a válaszadók tanulási stílus erôsségét jelzô változók és a játékos típus attitűd erősségét jelző változók annak érdekében, hogy láthassuk, találunk-e összefüggést a tanulási stílusok és a játékos attitűdök között (6. táblázat).

Az előzetes várakozásokkal ellentétben sajnos itt nem találtunk igazán erős korrelációs kapcsolatot. A legerősebb kapcsolatot az Elméleti tanulási stílus és a Felfedező játékos típus között láthatunk $(\mathrm{r}=0,319)$. A korreláció alapján ugyanakkor nem jelenthető ki egyértelmúen, hogy azon személyek, akik alapvetően modellekben gondolkodnak, azok a játékon belül is azok múködési logikáját próbálják modellezni, hiszen a vizsgálat nem ad visszajelzést az egyes változók erősségéről, csak annyi látható, a két változó értékei között (melyek mindkét változó esetén jelezhetnek közepes értéket is) felfedezhető egyfajta kapcsolat, azaz a válaszadók egy része hasonló erősséggel bírt mindkét attitűd esetén. 


\begin{tabular}{|c|c|c|c|c|c|}
\hline & & Achiever $\%$ & Killer \% & Explorer \% & Socializer $\%$ \\
\hline Tevékeny \% & $\begin{array}{l}\text { Pearson Correlation } \\
\text { Sig. (2-tailed) }\end{array}$ & $\begin{array}{l}-, 127 \\
, 173\end{array}$ & $\begin{array}{c}, 241 * * \\
, 009\end{array}$ & $\begin{array}{c}-, 253 * * \\
, 006\end{array}$ & $\begin{array}{l}, 058 \\
, 537\end{array}$ \\
\hline Töprengő \% & $\begin{array}{l}\text { Pearson Correlation } \\
\text { Sig. (2-tailed) }\end{array}$ & $\begin{array}{l}, 090 \\
, 334\end{array}$ & $\begin{array}{l}-, 130 \\
, 162\end{array}$ & $\begin{array}{l}, 201 * \\
, 030\end{array}$ & $\begin{array}{l}-, 089 \\
, 339\end{array}$ \\
\hline Elméleti \% & $\begin{array}{l}\text { Pearson Correlation } \\
\text { Sig. (2-tailed) }\end{array}$ & $\begin{array}{l}, 015 \\
, 874\end{array}$ & $\begin{array}{l}-, 179 \\
, 053\end{array}$ & $\begin{array}{c}, 319 * * \\
, 000\end{array}$ & $\begin{array}{l}-, 073 \\
, 431\end{array}$ \\
\hline Gyakorlati \% & $\begin{array}{l}\text { Pearson Correlation } \\
\text { Sig. (2-tailed) }\end{array}$ & $\begin{array}{l}, 019 \\
, 842\end{array}$ & $\begin{array}{l}-, 019 \\
, 843\end{array}$ & $\begin{array}{l}, 000 \\
, 999\end{array}$ & $\begin{array}{l}, 002 \\
, 981\end{array}$ \\
\hline
\end{tabular}

6. táblázat A tanulási stílus erősségét jelző változók és a játéktípus attitűd erősségét jelző változók korrelációja

A válaszadók esetén a cselekvő tanulási attitűd erőssége a gyakoriság adatok alapján elég alacsony a válaszadóknál, ugyanakkor pont ezen attitűd esetén láthatunk még kettő bár gyengén, de beazonosítható korrelációs kapcsolatot: Tevékeny - Killer $(\mathrm{r}=0,241)$ és Tevékeny - Explorer $(r=-0,253)$.

\section{Összefoglalás}

A felmérés eddigi eredményei alapján egyelőre úgy tűnik, hogy a tanulási stílusok, illetve a játékos típusok között kapcsolat sajnálatosan nem látszik. Ugyanakkor a kapott információk így is hasznosnak bizonyultak. Egyrészt találtunk kapcsolatot az egyes játékos típusok között, illetve a tanulási stílusok erősségét jelző változók között, amelyek már segíthetik a képzésfejlesztést, másrészt az előzetes minták alapján kitủnik, hogy amennyiben a képzést informatikai eszközök segítségével szeretnénk játékosítani, úgy célplatformként a számítógépek és az okos-telefonok jöhetnek szóba, hiszen ezek mind a játékok, mind pedig a tanulás tekintetében ez a két legsűrúbben használt felületek.

A kapott eredmények ellenére a kutatást azonban nem érdemes leállítani. A kérdőívből nyert minta alapján megfigyelhető, hogy a tanulási stílusok eloszlása elég egyenlőtlen, míg a válaszadók nagy része felsőfokú végzettséggel rendelkezik. A felmérés nem bizonyítja, de a végzettség feltételezhetően befolyással lehet az egyes személyek által kialakított tanulási stratégiákra. Célszerű lehet a kérdőívet kiterjeszteni szélesebb körre, abban a reményben, hogy az összehasonlítandó adatok homogénebbek lesznek.

\section{Felhasznált irodalom}

[1] BARTLE, Richard: Hearts, clubs, diamonds, spades: Players who suit MUDs. Journal of MUD research. 1996/1. szám.

[2] Deterding, Sebastian et al.: Gamification. Using game-design elements in nongaming contexts. In: CHI '11 Extended Abstracts on Human Factors in Computing Systems (CHI EA '11). Association for Computing Machinery, New York, 2011. pp. 2425-2428. https://doi.org/10.1145/1979742.1979575

[3] Deterding, Sebastian et al.: From Game Design Elements to Gamefulness: Defining "Gamification". In: Proceedings of the 15th international academic MindTrek conference: Envisioning future media environments 2011. pp. 9-15. https://doi.org/10.1145/2181037.2181040

[4] GASKÓ Krisztina et al.: Hatékony tanulás. Budapest Bölcsész Konzorcium, 2006. 
[5] KAPP, Karl M.: The gamification of learning and instruction: game-based methods and strategies for training and education, Pfeiffer, San Francisco 2012.

[6] KISs László: A hallgatók tanulási stílusa. SPECTRUM Mérnökiroda. http://www.spec.hu/tanulstilus.htm (Letöltve: 2021. március 29.)

[7] Sajtos László - MiTEV Ariel: SPSS Kutatási és adatelemzési kézikönyv. Alinea Kiadó, Bp., 2007.

[8] SuperData, A Nielsen Company. 2020. 2019 Year in Review - Digital Games and Interactive media. SuperData, A Nielsen Company, 2020. https://direc.ircg.ir/wpcontent/uploads/2020/01/SuperData2019YearinReview.pdf (Letöltve: 2021. március 29.)

[9] TóTH Péter: Tanulási stílus vizsgálata a szakképzésben. Empirikus kutatások a szakmai pedagógusképzésben. DSGI Ergonómiai Mérnöki Iroda Kft, Bp., 2013.

[10] Werbach, Kevin - Hunter, Dan: For the Win: How Game Thinking Can Revolutionize Your Business. Wharton Digital Press, Philadelphia, 2012.

\section{Lektor}

Simonics István, Dr., habil, egyetemi docens, Óbudai Egyetem Kandó Kálmán Villamosmérnöki Kar, Trefort Ágoston Mérnökpedagógiai Központ simonics.istvan@uni-obuda.hu 